\title{
Virulence gene profiles of Pasteurella multocida strains isolated from cattle and buffalo
}

\author{
Darioush Gharibi ${ }^{1 *}$, Mohammad R. H. Hajikolaei ${ }^{2}$, Masoud Ghorbanpour ${ }^{1}$, \\ and Seyyedeh K. Barzegar ${ }^{3}$
}

${ }^{1}$ Department of Pathobiology, Faculty of Veterinary Medicine, Shahid Chamran University of Ahvaz, Ahvaz, Iran

${ }^{2}$ Department of Clinical Sciences, Faculty of Veterinary Medicine, Shahid Chamran University of Ahvaz, Ahvaz, Iran

${ }^{3}$ Graduated of Veterinary Medicine, Shahid Chamran University of Ahvaz, Ahvaz, Iran

GHARIBI, D., M. R. H. HAJIKOLAEI, M. GHORBANPOUR, S. K. BARZEGAR: Virulence gene profiles of Pasteurella multocida strains isolated from cattle and buffalo. Vet. arhiv 87, 677-690, 2017.

\section{ABSTRACT}

Pasteurella multocida is responsible for numerous economically relevant diseases in domestic animals worldwide. In cattle and buffaloes the organism is associated with hemorrhagic septicemia (HS) and bovine respiratory disease (BRD). The aim of this study was to investigate twelve virulence associated genes in 22 strains of $P$. multocida isolated from slaughtered cattle and buffaloes. The most frequently detected genes among bovine isolates were $p t f A, n a n H$, exbBD-ton $B$ and $\operatorname{oma} 87$; whereas $h g b B$ and tox $A$ genes occurred less frequently. Some of the adhesions, sialidases, iron acquisition and protectin proteins occurred at considerably $(\mathrm{P}<0.05)$ higher frequencies in bovine isolates. The prevalence of oma87, exbBD-tonB and $h g b A$ genes from buffaloes was significant $(\mathrm{P}<0.05)$, whereas the prevalence of $h g b B$, ompH, pfhA and toxA genes was much lower. All tested strains of $P$. multocida contained the $\operatorname{sod} C$ gene and only $22.7 \%$ of them had $\operatorname{sod} A$. By using the virulence gene profiles, 12 and 21 different gene combinations were identified among the strains isolated from cattle and buffaloes, respectively, of which Profile $\mathrm{C} 1$ was the most common, with all strains possessing toxA. Our results indicate the presence of virulence factors $(\mathrm{VFs})$ in $P$. multocida strains isolated from the tested cattle and buffaloes. The occurrence of these factors in apparently healthy animals could possibly indicate early infection or a contained infection which did not lead to disease. Moreover, differences in the frequency of these factors may indicate variations in the pathogenicity of the organism.

Key words: virulence gene profile, Pasteurella multocida, buffalo, cattle

\footnotetext{
${ }^{*}$ Corresponding author:

Darioush Gharibi, Department of Pathobiology, Faculty of Veterinary Medicine, Shahid Chamran University of Ahvaz, Ahvaz, Golestan Bulevar, Postal code: 6135714333, Iran, Phone: +98 9132831 841; E-mail: d.gharibi@scu.ac.ir
} 
D. Gharibi et al.: Virulence gene profile of Pasteurella multocida from cattle and buffalo

\section{Introduction}

Respiratory infections cause considerable economic loss in sheep, cattle, buffalo, and other production animals. They often result from viral and bacterial infection interactions. One of the major bacterial etiologic agents in respiratory infections in farm animals is Pasteurella multocida (AHMAD et al., 2014). This organism is commonly found in the upper respiratory tract of humans and many animal species. It is responsible for numerous economically relevant diseases throughout the world, including hemorrhagic septicemia (HS) in cattle and buffaloes, bovine respiratory disease (BRD), fowl cholera (FC) in poultry, atrophic rhinitis (AR) in porcines, and snuffles in rabbits (GYLES et al., 2010). In humans, infection with $P$. multocida is usually associated with contact with animals, most usually through bites and scratches by pet animals, resulting in edema, cellulitis and bloody purulent exudate at the wound site (TAMASKAR and RAVAKHAH, 2004; ABRAHAMIAN and GOLDSTEIN, 2011). In severe cases, Pasteurella infection can rapidly progress to complications such as endocarditis, osteomyelitis and meningitis. Respiratory infection in humans is relatively uncommon, but may occur in patients with chronic pulmonary disease (BROOK, 2009; HEY et al., 2012).

HS is a serious acute and highly fatal disease affecting cattle and buffalo, caused by two specific serotypes of $P$. multocida. It is considered to be the economically most important disease in tropical regions of the world (RIMLER and WILSON, 1994; DABO et al., 2007). P. multocida serotype B:2 causes the disease in Asia, southern Europe and the Middle East, while serotype E:2 is the most common cause in Africa (TAYLOR et al., 1996). The disease is characterized by abrupt onset of high fever, lethargy, nasal discharge, respiratory distress, a rapid course of edematous swelling in the throat and brisket region, swollen and hemorrhagic lymph nodes, and widespread hemorrhaging (SHIVACHANDRA et al., 2011). In Iran the disease has an enzootic nature and has been associated with bovine death. It is endemic in Khouzestan, Mazandaran, Guilan, and western and eastern Azarbaijan (BAHARSEFAT and FIROUZI, 1977). In cattle and other ungulates, along with Mannheimia haemolytica, Trueperella pyogenes, Mycoplasma bovis, and Histophilus somni, P. multocida is implicated as a common pathogen related to BRD, or shipping fever (nonsepticemic pneumonia) (CONFER, 2009). The principal serotype of P. multocida isolated from most cases of shipping fever in cattle is A:3, manifesting usually as chronic bovine fibrinopurulent bronchopneumonia, pleurisy, and occasionally with fibrinonecrosis. BRD is a significant cause of morbidity and mortality in the cattle industry throughout the world (DABO et al., 2007; CONFER, 2009). Moreover, P. multocida may occasionally cause localized infections, abortion and mastitis in cattle (WELSH et al., 2004).

The pathogenesis of $P$. multocida is a result of complex interactions between special host factors and specific bacterial virulence factors (VFs). The major VFs that have been identified to date include lipopolysaccharide (LPS) and capsule protein (HARPER et al., 


\section{Gharibi et al.: Virulence gene profile of Pasteurella multocida from cattle and buffalo}

2006). However, many other virulence associated genes may be related, including genes encoding structures such as: iron acquisition related factors ( $h g b A, h g b B$, exbBD-tonB and $\operatorname{tbp} A$ ), bacterial adhesions and colonization factors (hsf-1, hsf-2, tadD, pfhA, ptfA and $f i m A$ ), outer membrane proteins (oma87, psl, ompA, ompH and $p l p B$ ), extracellular enzymes, such as superoxide dismutases $(\operatorname{sod} A, \operatorname{sod} C$ and $t b p A)$ and neuraminidase (nan $B$ and $n a n H$ ), and toxins (toxA) (HATFALUDI et al., 2010; KATOCH et al., 2014). The VFs of $P$. multocida may lead to a better understanding of the epidemiology, pathogenesis, protective immunity and vaccine development against $P$. multocida infections in hosts (TOMICH et al., 2007; HATFALUDI et al., 2010). There is now clear evidence that some $P$. multocida products are critical for virulence in some but not all hosts. Recently, EWERS et al. (2006) showed that tox $A$ alone is related to the disease status in swine, and $\operatorname{tbp} A$ and pfhal are associated with bovine diseases. Molecular techniques have been developed to identify genes associated with virulence in P. multocida, but the frequency of these genes in various hosts has not been clearly determined (GUENTHER et al., 2008; BETHE et al., 2009). The aim of this study was to investigate the presence of the virulence associated genes in strains of $P$. multocida isolated from cattle and buffalo in Khouzestan province, in south-west Iran.

\section{Materials and methods}

Bacterial strains. A total of 22 strains of $P$. multocida were used in this study. These organisms were isolated from 401 nasopharyngeal and nasal swab samples, randomly collected from slaughtered cattle and buffaloes (10 (4.4\%) strains out of 227 cattle swab samples and 12 (6.8\%) strains out of 174 buffalo swab samples) at the Ahvaz industrial abattoir in Khouzestan province, south-west Iran, during the period from October 2014 to June 2015. All the isolates had been already identified as P. multocida based on conventional cultural and biochemical tests, confirmed using polymerase chain reaction (PCR) technique, and by application of specific primers to kmt1. Also, capsular typing was performed by multiplex PCR using specific primers for the capsule biosynthesis genes. All samples were stored in sheep blood at a temperature of $-80{ }^{\circ} \mathrm{C}$.

DNA extraction. All isolates were initially cultured on 5\% sheep blood agar (Merck, Germany) plates and incubated at $37{ }^{\circ} \mathrm{C}$ for $24 \mathrm{hrs}$. Individual colonies were inoculated into test tubes containing $2 \mathrm{~mL}$ Tryptic Soy Broth (TSB) (Merck, Germany) and incubated at $37{ }^{\circ} \mathrm{C}$ for 18 to $24 \mathrm{hrs}$. An aliquot of $500 \mu \mathrm{L}$ of a TSB culture of each sample was separated for DNA extraction and heated at $100{ }^{\circ} \mathrm{C}$ for $10 \mathrm{~min}$, and then centrifuged for $10 \mathrm{~min}$ at 8500 g. $200 \mu \mathrm{L}$ of supernatant fluid was used for molecular tests and frozen at $-20{ }^{\circ} \mathrm{C}$ until further use. Prior to investigating virulence gene prevalence, a PCR protocol for species-specific amplification of the $k m t 1$ gene was performed (BOOM et al., 1990; EWERS et al., 2006). 
D. Gharibi et al.: Virulence gene profile of Pasteurella multocida from cattle and buffalo

Table 1. The virulence genes selected, their enzymatic function or process, the primer sequences and the size of the amplicons

\begin{tabular}{|c|c|c|c|c|}
\hline $\begin{array}{l}\text { Gene } \\
\text { function } \\
\text { and gene }\end{array}$ & $\begin{array}{l}\text { Process or } \\
\text { enzyme }\end{array}$ & Primer sequence $\left(5^{\prime}-3^{\prime}\right)$ & $\begin{array}{l}\text { Amplicon } \\
\text { size (bp) }\end{array}$ & References \\
\hline \multicolumn{5}{|l|}{ Adhesins } \\
\hline$p t f A$ & $\begin{array}{l}\text { type IV fim- } \\
\text { briae }\end{array}$ & $\begin{array}{l}\text { TGTGGAATTCAGCATTTTAGTGTGTC } \\
\text { TCATGAATTCTTATGCGCAAAATCCT- } \\
\text { GCTGG }\end{array}$ & 488 & $\begin{array}{l}\text { Doughty et } \\
\text { al. }(2000)\end{array}$ \\
\hline$p f h A$ & hemagglutinin & $\begin{array}{l}\text { AGCTGATCAAGTGGTGAAC } \\
\text { TGGTACATTGGTGAATGCTG }\end{array}$ & 275 & $\begin{array}{l}\text { Ewers et al. } \\
(2006)\end{array}$ \\
\hline \multicolumn{5}{|l|}{ Sialidases } \\
\hline $\operatorname{nan} B$ & sialidase & $\begin{array}{l}\text { GTCCTATAAAGTGACGCCGA } \\
\text { ACAGCAAAGGAAGACTGTCC }\end{array}$ & 554 & $\begin{array}{l}\text { Ewers et al. } \\
(2006)\end{array}$ \\
\hline nanH & sialidase & $\begin{array}{l}\text { GAATATTTGGGCGGCAACA } \\
\text { TTCTCGCCCTGTCATCACT }\end{array}$ & 360 & $\begin{array}{l}\text { Ewers et al. } \\
(2006)\end{array}$ \\
\hline \multicolumn{5}{|l|}{ Protectins } \\
\hline ompH & porin & $\begin{array}{l}\text { CGCGTATGAAGGTTTAGGT } \\
\text { TTTAGATTGTGCGTAGTCAAC }\end{array}$ & 438 & $\begin{array}{l}\text { Ewers et al. } \\
(2006)\end{array}$ \\
\hline oma 87 & porin & $\begin{array}{l}\text { ATGAAAAAACTTTTAATTGCGAGC } \\
\text { TGACTTGCGCAGTTGCATAAC }\end{array}$ & 948 & $\begin{array}{l}\text { Ewers et al. } \\
(2006)\end{array}$ \\
\hline \multicolumn{5}{|c|}{ Iron acquisition } \\
\hline $\begin{array}{l}\operatorname{exBD-} \\
\operatorname{ton} B\end{array}$ & $\begin{array}{l}\text { iron metabo- } \\
\text { lism }\end{array}$ & $\begin{array}{l}\text { GGTGGTGATATTGATGCGGC } \\
\text { GCATCATGCGTGCACGGTT }\end{array}$ & 1144 & $\begin{array}{l}\text { Ewers et al. } \\
(2006)\end{array}$ \\
\hline$h g b A$ & iron uptake & $\begin{array}{l}\text { TGGCGGATAGTCATCAAG } \\
\text { CCAAAGAACCACTACCCA }\end{array}$ & 419 & $\begin{array}{l}\text { Ewers et al. } \\
(2006)\end{array}$ \\
\hline$h g b B$ & iron uptake & $\begin{array}{l}\text { ACCGCGTTGGAATTATGATTG } \\
\text { CATTGAGTACGGCTTGACAT }\end{array}$ & 788 & $\begin{array}{l}\text { Ewers et al. } \\
(2006)\end{array}$ \\
\hline \multicolumn{5}{|l|}{ Toxins } \\
\hline $\operatorname{tox} A$ & $\begin{array}{l}\text { dermonecrotic } \\
\text { toxin }\end{array}$ & $\begin{array}{l}\text { CTTAGATGAGCGACAAGGTT } \\
\text { GGAATGCCACACCTCTATA } \\
\end{array}$ & 865 & $\begin{array}{l}\text { Ewers et al. } \\
(2006)\end{array}$ \\
\hline \multicolumn{5}{|c|}{ Superoxide dismutase } \\
\hline $\operatorname{sod} A$ & $\begin{array}{c}\text { superoxide } \\
\text { dismutase }\end{array}$ & $\begin{array}{l}\text { TACCAGAATTAGGCTACGC } \\
\text { GAAACGGGTTGCTGCCGCT }\end{array}$ & 361 & $\begin{array}{l}\text { Ewers et al. } \\
(2006)\end{array}$ \\
\hline $\operatorname{sod} C$ & $\begin{array}{l}\text { superoxide } \\
\text { dismutase }\end{array}$ & $\begin{array}{l}\text { AGTTAGTAGCGGGGTTGGCA } \\
\text { TGGTGCTGGGTGATCATCATG }\end{array}$ & 235 & $\begin{array}{l}\text { Ewers et al. } \\
(2006)\end{array}$ \\
\hline
\end{tabular}




\section{Gharibi et al.: Virulence gene profile of Pasteurella multocida from cattle and buffalo}

Detection of virulence genes. P. multocida strains were evaluated for the presence of twelve virulence related genes, including oma87, ompH, $p t f A, p f h A$, nanB, nanH, exBD$\operatorname{ton} B, h g b A, \lg b B, \operatorname{sod} A$, $\operatorname{sod} C$ and $\operatorname{tox} A$, using multiplex PCR in the presence of specific oligonucleotide primers. The sequence of each primer pair, the function of each one of the studied genes, and the predicted sizes of the amplified products for the specific primers used in this study are shown in Table 1.

In this study, three multiplex-PCR protocols were used (Table 2) in order to allow the simultaneous detection of selected virulence genes as described by EWERS et al (2006).

Table 2. Multiplex-PCR protocols: virulence associated genes and PCR conditions

\begin{tabular}{|c|c|c|c|c|c|c|}
\hline Multiplex & $\begin{array}{l}\text { Virulence } \\
\text { genes }\end{array}$ & Step & Function & $\begin{array}{c}\text { Temperature } \\
\left({ }^{\circ} \mathrm{C}\right)\end{array}$ & Time & $\begin{array}{l}\text { Number } \\
\text { of cycles }\end{array}$ \\
\hline \multirow{5}{*}{ Multiplex 1} & \multirow{5}{*}{$\begin{array}{l}\operatorname{sod} A, h g b A, \\
p t f A, p f h A\end{array}$} & First step & Initial denaturation & 95 & $5 \mathrm{~min}$ & 1 \\
\hline & & \multirow{3}{*}{ Second step } & Denaturation & 94 & $30 \mathrm{sec}$ & 25 \\
\hline & & & Annealing & 55 & $30 \mathrm{sec}$ & 25 \\
\hline & & & Extension & 72 & $1 \mathrm{~min}$ & 25 \\
\hline & & Third step & Final extension & 72 & $5 \mathrm{~min}$ & 1 \\
\hline \multirow{5}{*}{ Multiplex 2} & \multirow{5}{*}{$\begin{array}{l}\text { ompH, } \\
\text { exBD-tonB, } \\
\text { nanH, toxA }\end{array}$} & First step & Initial denaturation & 95 & $5 \mathrm{~min}$ & 1 \\
\hline & & \multirow{3}{*}{ Second step } & Denaturation & 94 & $30 \mathrm{sec}$ & 25 \\
\hline & & & Annealing & 55 & $30 \mathrm{sec}$ & 25 \\
\hline & & & Extension & 72 & $1 \mathrm{~min}$ & 25 \\
\hline & & Third step & Final extension & 72 & $5 \mathrm{~min}$ & 1 \\
\hline \multirow{5}{*}{ Multiplex 3} & \multirow{5}{*}{$\begin{array}{l}\text { oma } 87, \\
\operatorname{sod} C, \operatorname{hg} b B, \\
\operatorname{nan} B\end{array}$} & First step & Initial denaturation & 95 & $5 \mathrm{~min}$ & 1 \\
\hline & & \multirow{3}{*}{ Second step } & Denaturation & 94 & $30 \mathrm{sec}$ & 25 \\
\hline & & & Annealing & 55 & $30 \mathrm{sec}$ & 25 \\
\hline & & & Extension & 72 & $1 \mathrm{~min}$ & 25 \\
\hline & & Third step & Final extension & 72 & $5 \mathrm{~min}$ & 1 \\
\hline
\end{tabular}

For all reactions, $5 \mu \mathrm{L}$ of the DNA template was added to the $20 \mu \mathrm{L}$ mixture, containing $0.5 \mu \mathrm{L}$ of each primer (10 picomol), $1.5 \mu \mathrm{L}$ of $2.5 \mathrm{mM} \mathrm{MgCl}, 0.5 \mu \mathrm{L}$ of $10 \mathrm{mM}$ dNTPs, $2 \mathrm{U}$ of Taq DNA polymerase, $2.5 \mu \mathrm{L}$ of 10x PCR buffer, (all reagents made from SinaClon Bioscience Co., Iran), and sterile distilled water. The amplification reactions were performed in a thermocycler (Eppendorf, mastercycler gradient, Germany) according to the reaction conditions described in Table 2. $10 \mu \mathrm{L}$ of PCR products were separated by electrophoresis ( 100 volts for 1 hour) in a $1 \%$ agarose gel, stained with 0.5 $\mu \mathrm{g} / \mathrm{mL}$ safe stain. DNA fragments were visualized by UV transillumination (UVitec, the United Kingdom). The molecular size of the PCR products were compared with a $100 \mathrm{bp}$ DNA ladder (EWERS et al., 2006; FURIAN et al., 2013). In the present study, positive control strains of $P$. multocida were obtained from Aerobic Bacterial Vaccines Department, Razi 
Vaccine and Serum Research Institute, Karaj, Iran, and sterile water was the negative control.

Statistical analysis. The results were analyzed statistically using SPSS software version 19.0 (SPSS Inc., Chicago, IL). Descriptive statistics were computed to determine the proportions of the different VFs among the isolates. Chi square or Fisher's-exact tests were used for determination of the statistical significance of differences between the proportions, and $\mathrm{p}$-values of $<0.05$ were considered statistically significant.

\section{Results}

All isolates were screened for the presence of twelve different genes coding for VFs, and the results are given in Table 3. Among the 10 bovine $P$. multocida isolates, the twelve virulence gene prevalences ranged from $20 \%(\operatorname{tox} A)$ to $100 \%(\operatorname{sod} C)$. Some virulence genes, such as $p t f A$, nanH, oma87 and exbBD-tonB, were each found to occur in $90 \%$ of the strains. Our data show that these genes occur at significantly greater $(\mathrm{P}<0.05)$ frequency in bovine isolates of $P$. multocida. Of the adhesin-encoding genes studied, $p t f A$ $(90 \%)$ was more prevalent than $p f h A(60 \%$; $(\mathrm{P}<0.05)$, and of the sialidase-encoding genes, nanH $(90 \%)$ was more prevalent than $\operatorname{nanB}(60 \% ;(\mathrm{P}<0.05)$. Also, the results showed that only $20 \%$ of the tested bovine isolates had the tox $A$ gene and $40 \%$ of them had the $h g b B$ gene (Fig.1). Similarly, among the strains isolated from buffaloes, the virulence genes ranged in prevalence from $25 \%$ (toxA) to $100 \%$ (sodC) (Table 3$)$.

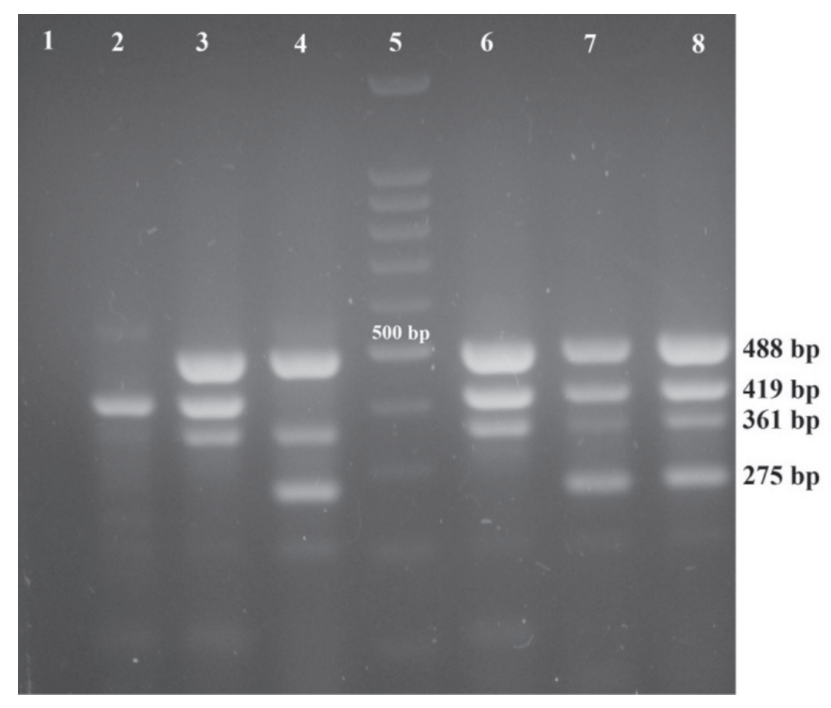


D. Gharibi et al.: Virulence gene profile of Pasteurella multocida from cattle and buffalo

Fig. 1. Electrophoresis on $1 \%$ agarose gel stained with safe stain and the amplification products associated with the genes studied (multiplex-PCR 1): pfhA (275 bp), sodA (361 bp), hgbA (419 bp) and ptfA (488 bp). Legend: $5=$ Marker (100 bp), $1=$ Negative control, 2-4 and 6-7 = Samples, $8=$ Positive control.

Most of the strains presented the oma87 and exbBD-tonB (91.6\%), and $h g b A(83.3 \%)$ genes $(\mathrm{P}<0.05)$. The type 4 fimbrial subunit encoding $p t f A$ and the sialidase-encoding nan $H$ genes were present in $75 \%$, and autotransporter protein nanB and superoxide dismutase $\operatorname{sod} A$ genes were present in $66.6 \%$ of the $P$. multocida strains isolated from buffaloes. With respect to the genes encoding hemoglobin-binding proteins, the most frequent was $h g b A(83.3 \%)$, followed by the $h g b B$ gene $(41.6 \% ; \mathrm{P}<0.05)$ and among the genes encoding outer membrane proteins, the oma87 $(91.6 \%)$ gene was more frequent than the ompH $(41.6 \% ; \mathrm{P}<0.05)$ gene. According to our results, all tested strains of $P$. multocida contained the sodC gene and only $22.7 \%$ possessed soda.

Table 3. Frequency of virulence genes in 22 strains of Pasteurella multocida isolated from cattle and buffalo

\begin{tabular}{|c|c|c|c|c|c|c|}
\hline \multirow[b]{2}{*}{$\begin{array}{l}\text { Virulence } \\
\text { genes }\end{array}$} & \multicolumn{2}{|c|}{ Positive strains (Cattle) } & \multicolumn{2}{|c|}{ Positive strains (Buffalo) } & \multicolumn{2}{|c|}{ Total positive strains } \\
\hline & $\begin{array}{c}\text { Total } \\
(\mathrm{n}=10)\end{array}$ & $\begin{array}{l}\text { Total } \\
(\%)\end{array}$ & $\begin{array}{c}\text { Total } \\
(\mathrm{n}=12)\end{array}$ & $\begin{array}{l}\text { Total } \\
(\%)\end{array}$ & $\begin{array}{c}\text { Total } \\
(\mathrm{n}=22)\end{array}$ & $\begin{array}{l}\text { Total } \\
(\%)\end{array}$ \\
\hline \multicolumn{7}{|l|}{ Adhesins } \\
\hline$p t f A$ & 9 & 90 & 9 & 75 & 18 & 81.8 \\
\hline$p f h A$ & 6 & 60 & 4 & 33.3 & 10 & 45.4 \\
\hline \multicolumn{7}{|l|}{ Sialidases } \\
\hline nanB & 6 & 60 & 8 & 66.6 & 14 & 63.6 \\
\hline nanH & 9 & 90 & 9 & 75 & 18 & 81.8 \\
\hline \multicolumn{7}{|l|}{ Protectins } \\
\hline ompH & 7 & 70 & 5 & 41.6 & 12 & 54.5 \\
\hline oma87 & 9 & 90 & 11 & 91.6 & 20 & 90.9 \\
\hline \multicolumn{7}{|c|}{ Iron acquisition } \\
\hline ex $B D$-ton $B$ & 9 & 90 & 11 & 91.6 & 20 & 90.9 \\
\hline$h g b A$ & 7 & 70 & 10 & 83.3 & 17 & 77.2 \\
\hline$h g b B$ & 4 & 40 & 5 & 41.6 & 9 & 40.9 \\
\hline \multicolumn{7}{|l|}{ Toxins } \\
\hline toxA & 2 & 20 & 3 & 25 & 5 & 22.7 \\
\hline \multicolumn{7}{|c|}{ Superoxidedismutase } \\
\hline $\operatorname{sod} A$ & 6 & 60 & 8 & 66.6 & 14 & 63.6 \\
\hline sodC & 10 & 100 & 12 & 100 & 22 & 100 \\
\hline
\end{tabular}




\section{Gharibi et al.: Virulence gene profile of Pasteurella multocida from cattle and buffalo}

In the present study, by using gene prevalence data, 12 and 21 different gene profile patterns (C1-12 and C1-21) were identified among P. multocida strains isolated from cattle and buffalo respectively, with collection $\mathrm{C} 1$ detecting all genes except toxA, and the most common in both groups of collections (Table 4).

Table 4. Distribution of gene combinations in 22 strains of $P$. multocida isolated from cattle and buffalo

\begin{tabular}{|c|c|c|c|c|c|}
\hline \multicolumn{3}{|c|}{ Collections in 10 strains isolated from cattle } & \multicolumn{3}{|c|}{ Collections in 12 strains isolated from buffalo } \\
\hline $\begin{array}{l}\text { Genetic } \\
\text { collection }\end{array}$ & $\begin{array}{l}\text { Number } \\
\text { of strains }\end{array}$ & Absent genes & $\begin{array}{c}\text { Genetic } \\
\text { collection }\end{array}$ & $\begin{array}{l}\text { Number } \\
\text { of strains }\end{array}$ & Absent genes \\
\hline $\mathrm{C} 1$ & 8 & toxA & $\mathrm{C} 1$ & 9 & $\operatorname{tox} A$ \\
\hline $\mathrm{C} 2$ & 6 & $h g b B$ & $\mathrm{C} 2$ & 8 & $p f h A$ \\
\hline $\mathrm{C} 3$ & 5 & toxA, $h g b B$ & $\mathrm{C} 3$ & 7 & ompH \\
\hline $\mathrm{C} 4$ & 4 & $n a n B$ & $\mathrm{C} 4$ & 7 & $h g b B$ \\
\hline $\mathrm{C} 5$ & 4 & $p f h A$ & $\mathrm{C} 5$ & 6 & toxA, $h g b B$ \\
\hline C6 & 3 & toxA, $h g b A$ & C6 & 6 & ompH, pfhA \\
\hline $\mathrm{C} 7$ & 3 & ompH, sodA & $\mathrm{C} 7$ & 5 & $\operatorname{sod} A$ \\
\hline $\mathrm{C} 8$ & 2 & nanB, pfhA & $\mathrm{C} 8$ & 5 & $h g b B, p f h A$ \\
\hline C9 & 2 & ompH, sodA, pfhA & C9 & 4 & $\operatorname{nan} B$ \\
\hline $\mathrm{C} 10$ & 1 & $p t f A$ & $\mathrm{C} 10$ & 4 & toxA, ompH \\
\hline $\mathrm{C} 11$ & 1 & oma87 & $\mathrm{C} 11$ & 4 & $p f h A, p t f A$ \\
\hline $\mathrm{C} 12$ & 1 & $\operatorname{ex} B D$-ton $B$ & $\mathrm{C} 12$ & 3 & nanH \\
\hline- & - & - & $\mathrm{C} 13$ & 3 & $p t f A$ \\
\hline- & - & - & $\mathrm{C} 14$ & 3 & ompH, nanH \\
\hline- & - & - & $\mathrm{C} 15$ & 3 & ompH, nanH, pfhA, ptfA \\
\hline- & - & - & $\mathrm{C} 16$ & 3 & ompH, toxA, $h g b B$ \\
\hline- & - & - & $\mathrm{C} 17$ & 2 & $h g b A$ \\
\hline- & - & - & $\mathrm{C} 18$ & 2 & $\operatorname{sod} A$ \\
\hline- & - & - & $\mathrm{C} 19$ & 2 & $h g b A, h g b B$ \\
\hline- & - & - & $\mathrm{C} 20$ & 1 & ex $B D$-ton $B$ \\
\hline- & - & - & $\mathrm{C} 21$ & 1 & oma87 \\
\hline
\end{tabular}

\section{Discussion}

Despite the high importance of infections caused by P. multocida, the pathogenicity and host specificity of the organism is not well understood (HARPER et al., 2006). There are only a few studies that have determined the frequency of VFs correlated with pathogenic mechanisms (EWERS et al., 2006; BETHE et al., 2009; TANG et al., 2009; FERREIRA et al., 2012; FURIAN et al., 2013; KHAMESIPOUR et al., 2014). VFs play a key 


\section{Gharibi et al.: Virulence gene profile of Pasteurella multocida from cattle and buffalo}

role in disease production by bacterial pathogens, and their major functions include competence, adherence, synthesis and export of capsules, and evasion of host immune responses (NANDURI et al., 2009). The present study has provided novel information on the prevalence and distribution of the various VFs of strains of $P$. multocida, isolated from cattle and buffalo.

The presence of adhesion proteins on the bacterial surface is usually associated with virulence, since they are known to play a crucial role in promoting host invasion and bacterial colonization (KLINE et al., 2009). Therefore, the related genes involved in this step are frequent targets for analysis of virulence genotypes in P. multocida (HATFALUDI et al., 2010). Studies by EWERS et al. (2006), using various clinically healthy and diseased hosts, and TANG et al. (2009) from clinical respiratory disease in pigs, have demonstrated that among the adhesins identified in samples of P. multocida, including $p f h A$, tad, ptfA, fim $A$, and $h s f-1,2$, only fim $A$ and hsf-1,2 were present in all pathogenic strains. The $p t f A$ gene, which encodes a subunit of type IV fimbriae, was described in $81.8 \%$ of the isolates tested in the current study, a result similar to that observed in other studies (TANG et al., 2009; FERREIRA et al., 2012; FURIAN et al., 2013; KHAMESIPOUR et al., 2014). The high prevalence of the $p t f A$ gene was expected since it has been identified as a key factor in bacterial attachment to the surface of the epithelial cells of hosts (EWERS et al., 2006). In contrast to the above mentioned adhesion related gene, the filamentous hemagglutinin gene $p f h A$ had a rather low prevalence $(45.4 \%)$ in P. multocida strains. This lower frequency was also found in other studies. EWERS et al. (2006) detected $p f h A$ in $46.2 \%$ of 104 bovine samples analyzed. Similarly, SHAYEGH et al. (2008) reported a low percentage of $p f h A$ in clinically healthy and diseased sheep, and observed a correlation between the presence of the gene and disease in ovines. Additionally, TANG et al. (2009) and FURIAN et al. (2013) detected $15 \%$ and $60 \%$ of phfA in associated strains of $P$. multocida isolated from swine with clinical respiratory disease, and fowl cholera, respectively.

The sialidases are enzymes that remove sialic acid conjugated to glycolipids and glycoproteins of eukaryotic cells (HATFALUDI et al., 2010). In the present study, two genes that encode sialidases, $n a n B$ and $n a n H$, were identified in $63.6 \%$ and $81.8 \%$ of isolates, respectively. The $n a n B$ gene was detected in all samples in other studies (EWERS et al., 2006; FURIAN et al., 2013), but was observed in $81.5 \%$ and $83.3 \%$ strains of $P$. multocida from clinical respiratory disease in pigs, and pneumonic and apparently healthy slaughter cattle, tested by TANG et al. (2009) and KHAMESIPOUR et al. (2014), respectively. The frequency of nanH was similar to that cited by KHAMESIPOUR et al. (2014), but it differs from EWERS et al. (2006), TANG et al. (2009), FERREIRA et al. (2012) and FURIAN et al. (2013) who detected this gene in $88.5 \%, 97 \%, 67.3 \%$ and $96 \%$ of samples, respectively.

The ompH and oma 87 genes, which encode porins of P. multocida, were detected in $54.5 \%$ and $90.9 \%$ of the analyzed samples, respectively. ompH and oma 87 genes were identified in all samples in other studies (DAVIES et al., 2004; EWERS et al., 2006; BETHE et al., 2009; FURIAN et al., 2013) and were the most frequently detected genes in isolates in 


\section{Gharibi et al.: Virulence gene profile of Pasteurella multocida from cattle and buffalo}

other studies (TANG et al., 2009; FERREIRA et al., 2012; KHAMESIPOUR et al., 2014). OmpH is a major outer membrane porin that forms a homotrimeric channel, and has shown some potential as a protective antigen (CHEVALIER et al., 1993). Oma87 is an 87-kDa outer membrane protein of all P. multocida strains that is expressed in vivo (RUFFOLO and ADLER, 1996). OmpH and Pasteurella lipoprotein E (PlpE) are protective surface antigens associated with $P$. multocida serotype A: 1, A: 3, and A: 4 strains isolated from cattle with shipping fever (WU et al., 2007; OKAY et al., 2012), and from birds with fowl cholera (HATFALUDI et al., 2012). Porins such as $\mathrm{OmpH}$ are candidates for heterologous vaccine development because they are generally conserved among species, and are highly immunogenic (LEE et al., 2007).

In this study, three genes involved in iron metabolism, exBD-tonB, $h g b A$ and $h g b B$, were detected in $90.9 \%, 77.2 \%$ and $40.9 \%$ of isolates, respectively. The high prevalence of the exBD-tonB and $h g b A$ genes was similar to that cited by other researchers (EWERS et al., 2006; BETHE et al., 2009; TANG et al., 2009; FURIAN et al., 2013; KHAMESIPOUR et al., 2014). In contrast, the low frequency of the $h g b B$ gene was also found in other studies. EWERS et al. (2006) detected $h g b B$ in $57.7 \%$ of bovine samples analyzed. FERREIRA et al., (2012) obtained similar results, detecting $h g b B$ less frequently $(30.4 \%)$ in strains of $P$. multocida isolated from rabbits. However, FURIAN et al. (2013) and KHAMESIPOUR et al. (2014) identified the $h g b B$ gene from $100 \%$ and $93.3 \%$ of poultry and bovine strains, respectively. The TonB complex, composed of three proteins, is responsible for the proton motive force required to internalize iron into the periplasmic space (KREWULAK and VOGEL 2008). The energy generated by the complex is required for different mechanisms of iron uptake (HATFALUDI et al., 2010). hgbA is an example of a protein present in the outer bacterial membrane that binds to host glycoproteins that contain iron, in this case hemoglobin (BOYCE et al., 2010).

All strains of $P$. multocida were positive for sodC, but $63.6 \%$ of them had $\operatorname{sod} A$. Our findings about the high frequency of $\operatorname{sod} C$ are similar to those found in other studies, but in contrast to the results of the present study, other researchers have also reported the high prevalence of soda (EWERS et al., 2006; FERREIRA et al., 2012; FURIAN et al., 2013; KHAMESIPOUR et al., 2014). The enzymes encoded by these genes have antioxidant functions, and they were only described after genome sequencing of the strain Pm70 in 2001 (MAY et al., 2001).

The toxA gene was only described in $22.7 \%$ of the isolates tested in the current study. The low prevalence of this gene may be related to the fact that the gene encoding dermonecrotic toxin is more frequent in atrophic rhinitis in swine. EWERS et al. (2006) also showed a low frequency of the gene, which was detected in only $5.8 \%$ of the strains isolated from cattle. Similarly, TANG et al. (2009) and KHAMESIPOUR et al. (2014) identified it in $4.7 \%$ and $10 \%$ of swine and bovine strains, respectively. Moreover, FERREIRA et al. (2012) and FURIAN et al. (2013) reported that none of the tested strains contained the toxA gene. However, SHAYEGH et al. (2008) detected the gene in $70 \%$ of strains isolated from diseased sheep. Some authors have reported that this gene is not 


\section{Gharibi et al.: Virulence gene profile of Pasteurella multocida from cattle and buffalo}

carried on the chromosome, but is carried on a lysogenic bacteriophage that infects the host (PULLINGER et al., 2004).

The generated virulence gene profiles of $P$. multocida were compared, and according to the presence or absence of the tested genes the strains isolated from cattle and buffaloes were clustered in 12 and 21 gene combinations, respectively. We performed analysis of the distribution of the genetic profiles in our samples, evaluating only the presence or absence of the genes among the samples. Acquiring strains from different origins and studying groups of samples isolated from healthy animals may reveal a possible epidemiological link between a specific group of genes, and shows the distribution of the carrier state to the organism between the tested animals. The virulence gene profile was found to be a good tool for differentiation of $P$. multocida strains.

In conclusion, our results reveal the presence of VFs in P. multocida strains isolated from tested cattle and buffaloes, and new epidemiological information on the prevalence of these various virulence factors. The occurrence of these virulence factors in apparently healthy animals could possibly indicate early infection, subclinical disease, or contained infection which did not lead to disease. Additionally, it is possible that the occurrence of these virulence factors without disease may be due to the fact that these factors are quiescent or the quantity of them is below a disease causing threshold. Also, since $P$. multocida is a facultative anaerobic bacterium that is commonly found in clinically healthy calves, isolation of this bacterium from the upper respiratory tract should not be neglected. In contrast, the pathogenicity of $P$. multocida depended on various virulence factors, and the number and differences in the frequency of these factors may indicate variations in the pathogenicity of the organism. Knowledge of the distribution patterns of $P$. multocida virulence factors will help to develop a suitable homologous vaccine candidate that can elicit protective immunity against all serotypes. However, further study is required to clarify the pathogenesis and the role of $P$. multocida virulence factors in immunity.

\section{Acknowledgements}

The authors would like to acknowledge the research vice of Shahid Chamran University of Ahvaz for financial support.

\section{Conflicts of interest}

The authors declare that they have no conflict of interest.

\section{References}

ABRAHAMIAN, F. M., E. J. GOLDSTEIN (2011): Microbiology of animal bite wound infections. Clin. Microbiol. Rev. 24, 231-246.

AHMAD, T. A., S. S. RAMMAH, S. A. SHEWEITA, M. HAROUN, L. H. EL-SAYED (2014): Development of immunization trials against Pasteurella multocida. Vaccine 32, 909-917. 
D. Gharibi et al.: Virulence gene profile of Pasteurella multocida from cattle and buffalo

BAHARSEFAT, M., S. FIROUZI (1977): Progress in control of Haemorrhagic septicaemia (Pasteurellosis) in cattle in Iran. Bulletin de I' Office International des Epizootics. 87, 622-625.

BETHE, A., L. H. WIELER, H. J. SELBITZ, C. EWERS (2009): Genetic diversity of porcine Pasteurella multocida strains from the respiratory tract of healthy and diseased swine. Vet. Microbiol. 139, 97-105.

BOOM, R., C. J. A. SOL, M. M. M. SALIMANS, C. L. JANSEN, P. M. E. WERTHEIM-VAN DILLEN, J. VAN DER NOORDAA (1990): Rapid and simple method for purification of nucleic acids. J. Clinic. Microbiol. 28, 495-503.

BOYCE, J. D., M. HARPER, I. W. WILKIE, B. ADLER (2010): Pasteurella, In: Pathogenesis of Bacterial Infections in Animals (Gyles, C. L., J. F. Prescott, G. Songer, C. O. Thoen, Eds), Ames: Blackwell Publishing. $4^{\text {th }}$ ed. pp. 325-346.

BROOK, I. (2009): Management of human and animal bite wound infection: an overview. Curr. Infect. Dis. Rep. 11, 389-395.

CHEVALIER, G., H. DUCLOHIER, D. THOMAS, E. SHECHTER, H. WROBLEWSKI (1993): Purification and characterization of protein $\mathrm{H}$, the major porin of Pasteurella multocida. J. Bacteriol. 175, 266-276.

CONFER, A. W. (2009): Update on bacterial pathogenesis in BRD. Anim. Health. Res. Rev. 10, 145-148.

DABO, S. M., J. D. TAYLOR, A. W. CONFER (2007): Pasteurella multocida and bovine respiratory disease. Anim. Health Res. Rev. 8, 129-150.

DAVIES, R. L., R. MacCORQUODALE, S. REILLY (2004): Characterization of bovine strains of Pasteurella multocida and comparison with isolates of avian, ovine and porcine origin. Vet. Microbiol. 99, 145-158.

DOUGHTY, S. W., C. G. RUFFOLO, B. ADLER (2000): The type 4 fimbrial subunit gene of Pasteurella multocida. Vet. Microbiol. 72, 79-90.

EWERS, C., A. LÜBKE-BECKER, A. BETHE, S. KIEBLING, M. FILTER, L. H. WIELER (2006): Virulence genotype of Pasteurella multocida strains isolated from different hosts with various disease status. Vet. Microbiol. 114, 304-317.

FERREIRA, T. S., M. R. FELIZARDO, D. D. SENADE GOBBI, C. R. GOMES, P. H. NOGUEIRA FILSNER, M. MORENO (2012): Virulence genes and antimicrobial resistance profiles of Pasteurella multocida strains isolated from rabbits in Brazil. Sci. World J. pp. 1-6.

FURIAN, T. Q., K. A. BORGES, S. L. S. ROCHA, E. E. RODRIGUES, V. P. DO. NASCIMENTO, C. T. P. SALLE, H. L. DE S. MORAES (2013): Detection of virulence-associated genes of Pasteurella multocida isolated from cases of fowl cholera by multiplex-PCR. Pesq. Vet. Bras. 33, 177-182.

GUENTHER, S., P. SCHIERACK, M. GROBBEL, A. L. BECKER, L. H. WIELER, C. EWERS (2008): Real-time PCR assay for the detection of species of the genus Mannheimia. J. Med. Microbiol. 75, 75-80.

GYLES, C. L., J. F. PRESCOTT, J. G. SONGER, C. O. THOEN (2010): Pathogenesis of Bacterial Infections in Animals. $4^{\text {th }}$ ed. Iowa: Wiley-Blackwell. pp. 325-346. 
D. Gharibi et al.: Virulence gene profile of Pasteurella multocida from cattle and buffalo

HARPER, M., J. D. BOYCE, B. ADLER (2006): Pasteurella multocida pathogenesis: 125 years after Pasteur. FEMS Microbiol. Lett. 265, 1-10.

HATFALUDI, T., K. AL-HASANI, J. D. BOYCE, B. ADLER (2010): Outer membrane proteins of Pasteurella multocida. Vet. Microbiol. 144, 1-17.

HATFAlUDI, T., K. AL-HASANI, L. GONG, J. D. BOYCE, M. FORD, I. W. WILKIE, N. QUINSEY, M. A. DUNSTONE, D. E. HOKE, B. ADLER (2012): Screening of 71 Pasteurella multocida proteins for protective efficacy in a fowl cholera infection model and characterization of the protective antigen PlpE. PLoS One. 7:e39973.

HEY, P., P. GOW, J. TORRESI, A. TESTRO (2012): Cirrhosis, cellulitis and cats: a 'purrfect' combination for life-threatening spontaneous bacterial peritonitis from Pasteurella multocida. BMJ Case Report, 2012-007397.

KATOCH, S., M. SHARMA, R. D. PATIL, S. KUMAR, S. VERMA (2014): In vitro and in vivo pathogenicity studies of Pasteurella multocida strains harbouring different ompA. Vet. Res. Commun. 38, 183-191.

DOI: $10.1007 / \mathrm{s} 11259-014-9601-6$

KHAMESIPOUR, F., H. MOMTAZ, M. AZHDARY MAMOREH (2014): Occurrence of virulence factors and antimicrobial resistance in Pasteurella multocida strains isolated from slaughter cattle in Iran. Frontiers in Microbiol. 5: Article 536;

DOI:10.3389/fmicb.2014.00536

KLINE, K. A., S. FALKER, S. DAHLBERG, S. NORMARK, B. HENRIQUES-NORMARK (2009): Bacterial adhesions in host-microbe interaction. Cell Host Microbe 5, 580-592. DOI:10.1016/j.chom.2009.05.011

KREWULAK, K. D., H. J. VOGEL (2008): Structural biology of bacterial iron uptake. Biochim. Biophys. Acta 1778, 1781-1804.

LEE, J., Y. B. KIM, M. KWON (2007): Outer membrane protein H for protective immunity against Pasteurella multocida. J. Microbiol. 45, 179-184.

MAY, B. J., Q. ZHANG, L. L. LI, M. L. PAUSTIAN, T. S. WHITTAM, V. KAPUR (2001): Complete genomic sequence of Pasteurella multocida, Pm70. Proc Nat. Acad. Sci. USA. 98, 3460-3465.

NANDURI, B., L. A. SHACK, S. C. BURGESS, M. L. LAWRENCE (2009): Proceedings: The transcriptional response of Pasteurella multocida to three classes of antibiotics. BMC Genomics. 10: Suppl 4, 1-10;

DOI: $10.1186 / 1471-2164-10-S 2-S 4$

OKAY, S., E. OZCENGIZ, G. OZCENGIZ (2012): Immune responses against chimeric DNA and protein vaccines composed of PlpEN-OmpH and PlpEC-OmpH from Pasteurella multocida A: 3 in mice. Acta Microbiol. Immunol. Hung. 59, 485-498.

PUllingeR, G. D., T. BEVIR, A. J. LAX (2004): The Pasteurella multocida toxin is encoded within a lysogenic bacteriophage. Molecul. Microbiol. 51, 255-269.

RIMLER, R. B., M. A. WILSON (1994): Re-examination of Pasteurella multocida serotypes that caused haemorrhagic septicaemia in North America. Vet. Rec. 134, 256. 
D. Gharibi et al.: Virulence gene profile of Pasteurella multocida from cattle and buffalo

RUFFOLO, C. G., B. ADLER (1996): Cloning, sequencing, expression, and protective capacity of the oma87 gene encoding the Pasteurella multocida 87-kilodalton outer membrane antigen. Infect. Immun. 64, 3161-3167.

SHAYEGH, J., S. ATASHPAZ, M. S. HEJAZI (2008): Virulence genes profile and typing of ovine Pasteurella multocida. AJAVA. 3, 206-213.

SHIVACHANDRA, S. B., K. N. VISWAS, A. A. KUMAR (2011): A review of hemorrhagic septicemia in cattle and buffalo. Anim. Health Res. Rev. 12, 67-82.

TAMASKAR, I., K. RAVAKHAH (2004): Spontaneous bacterial peritonitis with Pasteurella multocida in cirrhosis: case report and review of literature. South Med. J. 97, 1113-1115.

TANG, X., Z. ZHAO, J. HU, B. WU, X. CAI, Q. HE, H. CHEN (2009): Isolation, antimicrobial resistance and virulence genes of Pasteurella multocida strains from swine in China. J. Clinic. Microbiol. 47, 951-958.

TAYLOR, S. K., A. C. WARD, D. L. HUNTER, K. GUNTHER, L. KORTGE (1996): Isolation of Pasteurella spp. from free-ranging American bison (Bison bison). J. Wild Dis. 32, 322-325.

TOMICH, M., P. J. PLANET, D. H. FIGURSKI (2007): The tad locus: postcards from the widespread colonization island. Nat. Rev. Microbiol. 5, 363-375.

WELSH, R. D., L. B. DYE, M. E. PAYTON, A. W. CONFER (2004): Isolation and antimicrobial susceptibilities of bacterial pathogens from bovine pneumonia: 1994-2002. J. Vet. Diagn. Invest. 16, 426-431.

WU, J. R., J. H. SHIEN, H. K. SHIEH, C. F. CHEN, P. C. CHANG (2007): Protective immunity conferred by recombinant Pasteurella multocida lipoprotein E (PlpE). Vaccine 25, 4140-4148.

Received: 27 July 2016

Accepted: 14 July 2017

GHARIBI, D., M. R. H. HAJIKOLAEI, M. GHORBANPOUR, S. K. BARZEGAR: Profil gena za virulenciju izolata bakterije Pasteurella multocida izdvojenih iz goveda i bivola. Vet. arhiv 87, 677-690, 2017. SAŽETAK

Pasteurella multocida odgovorna je za mnoge gospodarski važne bolesti domaćih životinja diljem svijeta. U goveda i bivola ta je bakterija povezana s pojavom hemoragijske septikemije (HS) i respiratorne bolesti. Cilj je ovog rada bio istražiti prisutnost 12 gena odgovornih za virulenciju u 22 izolata bakterije $P$. multocida izdvojena iz zaklanih goveda i bivola. Najčešće dokazani geni iz goveđih izolata bili su $p t f A$, nanH, exbBD-tonB i oma 87 , dok su geni $h g b B$ i tox $A$ bili rjeđe dokazani. Neki od adhezina, sijalidaza, proteina koji na sebe vežu slobodno željezo i zaštitnih proteina dokazani su sa znatno većom učestalošću $(\mathrm{P}<0,05)$ u goveđih izolata. Prevalencija gena oma 87 , exbBD-tonB i $h g b A$ bila je značajno viša $(\mathrm{P}<0,05)$ dok je prevalencija gena $h g b B$, ompH, $p f h A$ i toxA bila niža u bivoljih izolata. Svi pretraženi izolati bakterije $P$. multocida sadržavali su gen $\operatorname{sod} C$, a samo $22,7 \%$ njih i gen sodA. S obzirom na profil gena za virulenciju, 12 različitih kombinacija ustanovljeno je među izolatima iz goveda, a 21 kombinacija među izolatima iz bivola od kojih je profil C1 bio najčešći u izolata koji su posjedovali toxA. Rezultati naznačuju prisutnost čimbenika virulencije u izolata bakterije $P$. multocida izdvojenih iz pretraženih goveda i bivola. Pojava tih čimbenika virulencije u klinički zdravih životinja mogla bi značiti ranu infekciju ili infekciju koja se neće klinički očitovati. Razlika u učestalosti spomenutih čimbenika također upućuje na različitost u patogenosti izolata.

Ključne riječi: virulencija, genski profil, Pasteurella multocida, bivol, govedo 